\title{
De-ideologization, liberation psychology, and the place of contradiction
}

\author{
Nick Malherbe ${ }^{1,2}$ (])
}

${ }^{1}$ Institute for Social and Health Sciences, University of South Africa, Lenasia, South Africa

${ }^{2}$ Masculinity and Health Research Unit, South African Medical Research CouncilUniversity of South Africa, Cape Town, South Africa

\section{Correspondence}

Nick Malherbe, Institute for Social and Health Sciences, P. O. Box 1087, Lenasia 1820, South Africa.

Email: nicholas.malherbe@mrc.ac.za

\begin{abstract}
In following Marxist and psychoanalytic theory, we can understand ideologies as social processes that obscure the contradictions (i.e., how an object is not at one with itself) inherent to individual subjectivity and social structures. Despite claiming to be non-ideological, mainstream psychology has, throughout its history, served the ideological interests of elite classes (e.g., by pathologizing political resistance). Working within the liberation psychology paradigm, I attempt in this article to elaborate on the notion of de-ideologization (i.e., the politically committed retrieval of people's experiences beyond the ideological reference points of elite classes) through a consideration of contradiction. To do this, I explore how de-ideologization can connect with contradiction through processes of re-symbolization, solidarity-making, and mobilizing progressive ideologies. Considered together, these three processes allow us to use contradiction to understand interlocking currents of oppression, divergent visions of emancipation, the development of insurgent subjectivities, and the building of an intersectional socialist politics. In conclusion, I consider some of the directions that theoretical and praxis-oriented work on de-ideologization may take, as well as some paths it may wish to avoid.
\end{abstract}

\section{K E Y W O R D S}

collective resistance, contradiction, de-ideologization, ideology, liberation psychology 


\section{1 | INTRODUCTION}

The notion of ideology has entered into popular parlance as well as academic and political discourse in numerous, often discordant, ways (Eagleton, 1991). For some, it is only our enemies who are ideological, while for others, ideology is inescapable, perhaps even more so when we feel that we have transcended it (Žižek, 1989, 2020). Others, still, have perceived of ideology as a set of stable ideas; a view which has been countered by those who understand it as an ongoing social process (Althusser, 2014; Therborn, 1980). Drawing on critical traditions of ideology scholarship, critical psychologists have long averred that mainstream psychology has, since its inception, been wielded as an ideological tool for advancing elite interests (e.g., rendering structural violence the result of psychological maladjustment, or pathologizing political resistance), all while laying claim to universality (see, e.g., Billig, 1991; Esposito \& Perez, 2014; Parker, 2007; Teo, 2018). What, one might then ask, are the ideological limits and possibilities of a psychology that strives to be ethical, critical, and democratic, and that serves the interests of oppressed peoples (i.e., a psychology of liberation, see Malherbe, 2018; Martín-Baró, 1994; Montero, 2007; Ratner, 2019a)?

My partisan objective in this article is to flesh out how ideological critique can inform Ignacio Martín-Baró's (1994) conception of de-ideologization, which denotes a process, within the liberation psychology paradigm, of retrieving people's experiences beyond the ideological reference points of elite classes (see also Montero, 1997). I argue that if we wish to mobilize against oppressive ideologies and create new, emancipatory ones, the issue of locating and exploiting ruptures within dominant ideology is crucial (see Žižek, 1989). Accordingly, the central theoretical link between de-ideologization and a critical conception of ideology is, I claim, contradiction, which we can understand as the way a subject or system is not at one with itself, that is, the immanent points of tension or incoherence within a social or symbolic order (see McGowan, 2019). Accordingly, I make use of psychoanalytic and Marxist formulations of ideology, wherein contradiction has been of central theoretical import, to elaborate on and explore further Martín-Baró's (1994) conception of de-ideologization.

In what follows, I draw on Marxist and psychoanalytic thought to provide a brief overview of how ideology has been conceptualized in relation to the formation of individual subjectivity and social systems, and the central role that contradiction plays here. By no means do I provide an exhaustive account of this extensive literature. Instead, it is recounted insofar as it relates to the proceeding discussion on de-ideologization. Following this, I consider how critical psychology has evaluated mainstream psychology's ideological allegiances, and how these allegiances informed Martín-Baró's (1994) conception of de-ideologization. From here, I seek to bring psychoanalytic and Marxist theory on ideology and contradiction to bear on the notion of de-ideologization by examining three de-ideologizing processes which those working within the liberation psychology paradigm may enter into when working with collective resistance efforts, namely: re-symbolization, solidarity-making, and mobilizing progressive ideologies. I demonstrate how each of these three processes harnesses contradiction to better understand interlocking currents of oppression, divergent visions of emancipation, the development of insurgent subjectivities, and the building of an intersectional socialist politics, thereby stretching the perceived possibilities of de-ideologization. In conclusion, I reflect on some of the directions that theoretical and praxis-oriented work on de-ideologization may take, as well as some paths we may wish to avoid here. 


\section{2 | THE IDEOLOGICAL PRODUCTION OF SUBJECTIVITIES AND SOCIAL SYSTEMS}

Carl Ratner (2019b) insists that because ideology is so central to the formation of social systems (i.e., the interacting structures within which people live, Galtung, 1990), we should seek to understand how ideology produces human subjectivities (i.e., how the self is constituted, as a psychological agent, within social systems or institutions, Therborn, 1980). In what follows, I am less concerned with theories of ideology that deal with socio-historical specificities than I am with how ideology grips and exerts power over psychological subjects as they exist within particular social systems (see Glynos, 2001). This is to say, I am concerned primarily with how ideology affects the consciousness of social actors, how political subjects resist ideological currents, and how ideology influences the formation of society as well as the institutionalized thought systems (i.e., the dominant discourses) of a given society (see Therborn, 1980).

Although the notion of ideology as a 'science of ideas' was popularized in the late eighteenth century by the French idealogues, and by Antoine Destutt de Tracy in particular (Balibar, 1995), for many on the political left, ideology is most often associated with Marx and Engels (1972), who used the concept to refer to society's most powerful ideas which, they argued, are determined by the ruling classes who own the means of production. Thus, in the Marxian formulation, ideology works to legitimize the capitalist social order by making class antagonisms appear cultural, natural, or the product of individual will, rather than an inherent feature of capitalism (Žižek, 2020). In other words, for Marx, we are able to know the objective laws of capitalism, and anything that denies this knowledge is ideological. It is, therefore, this false ideological knowledge that must be replaced with true knowledge (Glynos, 2001). It follows, then, that within the Marxian understanding of ideology, the key to changing oppressive ideological formations and revolutionizing subjective consciousness is a democratic restructuring of the division of labor and surplus value (i.e., ensuring workers' control of both the processes and products of production). Ideological change is, in this regard, always overdetermined by class struggle (Therborn, 1980).

Some have argued that Marx and Engels (1972) offer a somewhat deterministic view of ideology. Exemplary here is the thought of Louis Althusser. Drawing on Lacanian psychoanalysis, but retaining Marx's materialist conception of ideology, Althusser (2014) proposed that ideology interpellates_-or hails — us as subjects, and in so doing indicates what is right and possible for particular subjects. Thus, rather than a stable body of ideas that can be possessed, Althusser understood ideology as an ongoing social process to which we all subscribe (Therborn, 1980). Linking this conception of ideology to the signification of political power (Eagleton, 1991), Althusser (2014) proposed that ideological State apparatuses, such as schools, government, and the legal system, hail us as subjects in ways that are conducive to the reproduction of capitalism (Augoustinos, 1999). Not only do we become subjects through the gaze of these dominant institutional powers, but we also come to recognize ourselves as subjects through this gaze. In this, ideology offers to us an illusionary psychic fullness that obscures the contradictions of social structures as well as individual subjectivity (Bloom, 2013; Malherbe, 2021). As such, ideology sustains our desires by instructing us how to desire (Glynos, 2001; Kornbluh, 2019).

Althusser has been critiqued for overlooking human agency, how we are ideologically motivated by what we do not 'know' in the conscious sense, as well as emancipatory ideologies (Therborn, 1980). In his critical reading of Althusser (2014), Slavoj Žižek (1989) contends that ideology holds within it repressed content. Accordingly, ideological fantasy does not permit us an escape from material reality. Rather, it offers us an escape from the trauma of the Lacanian Real (i.e., that which we fail to symbolize and give meaning to through language) by eliminating 
structural and subjective contradiction (see Bloom, 2013; Malherbe, 2021). In this way, ideology attempts to give concrete content to a symbolic order that is inherently lacking (Glynos, 2001; Laclau, 1996). Despite the failure of the subject to constitute a structurally stable identity, ideology allows us to make sense of complex, contradictory, and sometimes unutterable experiences (Malherbe, 2021), and it is in this regard that ideology achieves hegemony through people's consent (Hall, 1987); symbolizing our experience so as to win our complicity (Eagleton, 1991) and determine 'common sense' (Augoustinos, 1999). To successfully transgress subjective and structural contradiction, though, ideology requires a fantasy into which we can escape our dissatisfactions and that depresses insurgent universalities (McGowan, 2019). The capitalist fantasy of material success, supposedly available to all through hard work, is perhaps the obvious example in this respect. The point that Žižek (1989) makes here is that although people are undoubtedly aware of the falsity of ideology's promises, they nonetheless adhere to ideology, seeking solace in its illusionary offers of wholeness.

In considering the above, Todd McGowan (2019) offers a useful working definition of ideology, noting that it transforms inherent contradictions into external oppositions. Celebrating a diversity of opposition, as is the wont of neoliberal capitalism, makes difficult the articulation of an emancipatory form of political inquiry (Holland, 2017). For instance, when we use opposition, rather than contradiction, as a hermeneutic frame, capitalists and workers appear to confront one another in an external relationship, with each made to seem independent from the other. However, when contradiction serves as our interpretive frame, we can understand how capitalists, as well as the overarching capitalist system, are produced through the exploitation of workers. Similarly, ignoring contradiction papers over the ways by which subjects do not feel at one with the various subjectivities by which they are hailed; making feelings of subjective alienation seem like the product of one's dysfunctional psyche, rather than of human subjectivity as such (see Malherbe, 2021).

For purposes of social domination and control, a coherent ideology is much less important than how ideologies are used to maintain societal divisions (Eagleton, 1991; Therborn, 1980). The falsely unified ideological subject is always constructed with reference to a negative subject which apparently infringes upon one's ability to achieve subjective unity. Hinging perceptions of one's own subjectivity on the negative- or 'bad'—-subjectivities of the Other may then be used by people to justify violence against those who embody this Other subjectivity (Foster et al., 2005). Yet, although what one experiences (e.g., xenophobia) may be real, this reality is not grounded in truth (i.e., it is not the foreigner that threatens one's wellbeing, but rather the economic precarity brought about by a capitalist political economy), meaning that it is a reality denuded of meaning (see Eagleton, 1991; Žižek, 2014).

Dominant ideologies are always rooted historically and do not appear spontaneously. They become legitimized through universalization, naturalization, the promotion of certain beliefs, the denigration and exclusion of others, and obfuscation (Eagleton, 1991). It is through ideology that capitalism offers us much of the same under the guise of constant change and innovation, adapting itself to vastly different societies and cultural milieus (Žižek, 2014). By determining what is true, possible, good, correct, legitimate and what should and should not exist (see Foster et al., 2005), ideology can block off alternative visions of life (Hall, 1987). At the same time, though, our consenting to ideology is not necessarily the result of 'false consciousness'. It is more likely fear of retribution from the State or employers that resigns people to their ideological adherence (Therborn, 1980).

Through ideology, we experience our unfreedom as freedom (e.g., the right to choose healthcare rather than receiving healthcare no matter what), and we realize identity through 
fundamentally hollow and unsatisfactory consumer choices (Augoustinos, 1999; Harvey, 2017; Žižek, 2020). Yet, ideology is also the medium through which people make history as conscious actors (Therborn, 1980), and while it can be difficult to 'escape' ideology altogether, the rigidness of our ideological presuppositions can certainly be challenged (Eagleton, 1991). Ideological critique can, in turn, create the necessary conditions for aligning with different ideologies that hail subjects in accordance with the requirements of an emancipatory political project (Malherbe, 2021).

\section{3 | MAINSTREAM PSYCHOLOGY AND IDEOLOGY}

If, with Tissaw and Osbeck (2007, p. 158), we understand mainstream psychology as 'a conception of psychology-as-science and commitment to experimental methods as the basis of inquiry', then we might say that such a psychology always attends to ideological interests of some kind. I wish to argue in this section that mainstream psychology's relationship to ideological obscurantism serves elite interests and can be observed on two plains: ideological denial and individualization.

\section{1 | Ideological denial}

Mainstream psychology is, by and large, ideologically invested in the social order in which it is embedded and tends to be drawn on to adapt people to this order, rather than change or subvert it (Parker, 2007). Accordingly, Michael Billig (1991) argues that far from being rooted in fact, the discipline of psychology tends to rely on factual rhetoric, the success of which depends in large part on how convincingly this rhetoric speaks to and reformulates dominant ideology. It is very often the values and interests of middle-to-upper-class populations from the Global North which are taken as the ideological norm within psychology (Roberts, 2015; Teo, 2018). Through continued institutional attempts to establish mainstream psychology as a natural-rather than a human-science, we see the adherents of this kind of psychology attempt to furnish it with scientific credence by denying its ideological allegiances (see Teo \& Afşin, 2020). In other words, psychology's insistence on universalism conceals its ideological rootedness in Western liberal individualism so that it can appear to function, in a seemingly apolitical fashion, outside of ideology (Augoustinos, 1999; Parker, 2007; Roberts, 2015). This ideological insistence on psychology's scientific grounding, Thomas Teo (2018) maintains, disincentivizes the construction of liberatory psychologies from below (i.e., psychologies which work with-rather than on-people).

Psychology tends to create 'enemies' against which it can hail well-adjusted, 'whole' capitalist subjects (Foster et al., 2005; Malherbe, 2021; Parker, 2007). These subjects are understood to occupy a 'permanent psychological present' (Martín-Baró, 1994. p. 30) that is removed from the ideological contradictions of history and society. It is here that mainstream psychology offers itself to this 'subject-removed' as a relevant, natural science that operates beyond ideological misgivings (see Parker, 2007). In this way, psychology confines human agency to consumerism (see Esposito \& Perez, 2014), with the subject made into a stable and knowable entity that is to be managed by the psychologist (Ratner, 2019b). Psychology, in this sense, has become yet another capitalist commodity (which, like all commodities, is shot through with ideology) that is to be bought, sold, and advertised in the marketplace, with little to say on the ethical, the social, or the political (Teo \& Afşin, 2020). A psychology of this sort is likely to make those who subvert or resist capitalism and its attendant ideologies into problems (Teo, 2018). 


\section{2 | Individualization}

Within much psychology, ideology is understood as a formal belief system that is internally consistent, even if it is the result of 'faulty cognition' (Augoustinos, 1999). When mainstream psychology does address itself to questions of ideology (while usually still denying itself as ideological), it tends to divorce ideology from its material context. As such, ideology is individualized and made to seem like one among many ways of seeing the world (Parker, 2007). The societal embeddedness of power and contradiction is, in this sense, muted, brushed over, or ignored (Dobles, 1999). As such, individual subjects (and corresponding psychological concepts, such as personality, the self, IQ, and mental illness) are made to appear asocial so that an individualist, psychologizing ideology can serve as the primary lens through which to understand reality; with the socioeconomic structure of the world reduced to bodies and brains (Roberts, 2015). In other words, social inequalities are made into products of the individual, with overcoming oppression understood by much mainstream psychology as a matter of self-regulation or adapting an individual to systemically violent social arrangements (Danziger, 1990; Parker, 2007). In turn, the mental health implications of capitalism's structurally dehumanizing apparatuses are, paradoxically, ignored within many of psychology's mainstream iterations (Malherbe, 2018; Teo, 2018).

By individualizing ideology, it becomes difficult for psychological subjects to move from feeling (and the kinds of knowing which come with feeling, see Malherbe, 2021) to social action (see Teo, 2018). As Ian Parker (2007) somewhat sardonically notes, much of mainstream psychology encourages replacing activism and solidarity with charity and antidepressants. In this way, psychology assists in the neoliberal project of privatizing social responsibility while little-to-no responsibility is demanded from corporations (Roberts, 2015). In response to this, several psychologists have called for a critical reappraisal of how ideology is conceptualized within psychology (see Ratner, 2019b), and for those who practice psychology to refuse how the discipline has bolstered capitalist ideology by hailing docile, inactive subjectivities (Roberts, 2015). A reappraisal of this sort requires interrogating how ideology influences the constitution of subjectivity as it is embedded within social reality (Augoustinos, 1999). Although there are numerous strands of psychology which have sought to take up the task of critically reappraising ideology and its effects on subjectivity and society, an especially useful—and perhaps also rather neglected—paradigm has been proposed by Martín-Baró (1994), whose work I turn to in the next section.

\section{4 | DE-IDEOLOGIZATION AND LIBERATION PSYCHOLOGY}

Martín-Baró (1994) argued that a psychology of liberation is committed to the task of shifting attention away from the discipline of psychology and towards the psychosocial needs of majority populations. Questions of ideology are, for Martín-Baró, fundamental to this task. Drawing from Marxian formulations of ideology (see Dobles, 1999; Malherbe, 2018), he understood oppressive ideology as the disguised exercise of dominant power (Burton \& Kagan, 2005). MartínBaró (1994) argued that although it is oppressive power-rather than ideas-that dominates (see Eagleton, 1991), such power is only able to achieve hegemony through ideological processes that deny, distort, and obscure exploitation and oppression (Montero, 1994, 1997). Ideology, in other words, naturalizes power and compels people to reproduce its dictates and internalize its commands, all while fragmenting political consciousness (Dobles, 1999; Montero, 1997).

In thinking through how subjectivity and identity can be drawn on for purposes of political mobilization (Burton \& Kagan, 2005), Martín-Baró (1994) claimed that psychologists should 
work with people to de-ideologize their everyday experiences. By this, he meant a politically committed retrieval of people's experiences beyond the ideological reference points of elite social classes. We may, then, not only talk about—but also make sense of-society, history, politics, and subjectivity in ways that rely on an ideological hermeneutic from below, one that speaks to the material experiences of the oppressed majority (see Watkins \& Shulman, 2008). To de-ideologize requires that we demonstrate how experience can represent a kind of objective knowledge that is structurally rooted in capitalist political economy, rather than individual opinion (Ratner, 2019a). Work of this kind seeks to counteract fatalism or symbolic loss (both of which are essential to ideology, see McGowan, 2019; Žižek, 1989) through memories, cultures, and values that are at lodged within individual subjectivities as well as social systems (Watkins \& Shulman, 2008). Yet, because people's memories of emancipation and political insurgency tend to be distorted, suppressed or ignored, we cannot 'retrieve' them wholesale. Rather, people can recover, remake, reconstitute, reconstruct and/or reorganize these memories in ways that speak to their present conjuncture (Malherbe, 2020). This non-linear process of retrieval, we might say, lends itself well to the notion of contradiction.

In what Martín-Baró (1994) called the Social Lie, people are confronted with a reality whose ideological makeup is compatible with ruling class interests and which restrains solidarity among the oppressed (Featherstone, 2012; Ratner, 2019a). Through the notion of realismo crítico, Martín-Baró (1994) insisted that social problems and action must define theory, and not the other way around. By drawing on methodological eclecticism (see Burton \& Kagan, 2005), de-ideologization can assist oppressed classes in confronting the kinds of contradictions that ideology seeks to conceal. In so doing, groups of people-rather than dominant ideological powers or State apparatuses - can make sense of their own realities. We must, therefore, look to what is missing from dominant ideologies if we are to develop meaningful counter-hegemonies (Malherbe, 2020; Montero, 1997). 'Truth', in this sense, is to be found among the oppressed (Montero, 2007), with psychological concepts formed and remade through indigenous knowledges and experiences (Watkins \& Shulman, 2008).

De-ideologization, for Martín-Baró (1994), was rarely considered without reference to Paulo Freire's (1972) notion of conscientization, which denotes a cognitive and emotional process of transformation that looks to liberate oppressed and oppressor by ensuring that emancipatory social action is informed by an awareness-or understanding-of society's structural determinants (see also Montero, 2007). Conscientization can assist psychologists to work with others to develop an awareness of the political nature of subjectivity, and how societal changes can bring about more liberating subjective hails (see Ratner, 2019a; Therborn, 1980). Action and reflection, therefore, occur together (Freire, 1972), and it is through this always-developing critical understanding of the self, groups, and the world that people can work together to illuminate (or symbolize) the repressed content of dominant ideology (Montero, 1994, 1997).

It should be noted that liberation psychology is, itself, not exempt from the requirements of de-ideologization, which is to say that liberation psychology must guard against ideological recuperation. For instance, Fernando González Rey (2016) recounts that those psychologists who understand their work as situated within the liberation psychology paradigm oftentimes draw on this paradigm as a rhetorical identity space, wherein a leftist subjectivity is constructed for purposes of self-promotion. We saw similar modes of ideological recuperation during the 1960s when the anti-psychiatry movement devolved into demands for consumerist reform (Esposito \& Perez, 2014). De-ideologization thus calls upon psychologists to institute a continual and reflexive engagement with their work (Malherbe, 2018). As such, de-ideologization does not necessitate escaping ideology altogether (whether this is even possible is, of course, up for debate and 
perhaps also beside the point), but rather looks to dispel oppressive capitalist ideologies so that we may begin to construct new, emancipatory ones (see Malherbe, 2020). Although Martín-Baró and Marx argued that emancipatory ideologies of this sort should reflect a socialist politics, I would add that if de-ideologization efforts are to address the expansive nature of neoliberal capitalism by accruing a necessarily broad and sustainable appeal, such efforts must strive towards an intersectional socialism that takes seriously those histories of anti-capitalism that are grounded in feminist, decolonial, and ecological struggle (see Bohrer, 2019; Davis, 2016; Featherstone, 2012).

\section{5 | DE-IDEOLOGIZATION AND COLLECTIVE RESISTANCE}

David Harvey (2017) notes that, far from a singular event, social transformation is likely to take place across different moments, such as social relations, material (re)production, everyday life, people's psychic conceptions, and social institutions. If de-ideologization is to be used with any effect, then, it should not be considered an emancipatory process in and of itself, but rather as a tool that can inform how people resist and remake various moments within capitalism. In other words, because emancipation from oppressive ideology is a necessary precondition for emancipation from oppressive social relations (Holland, 2017), we cannot perceive of de-ideologization as separate from actually existing social, political, cultural, material, and moral struggles (see Wright, 2019). In what proceeds, I consider three de-ideologizing processes into which psychologists may enter when working with and for collective resistance efforts, namely: re-symbolization, solidarity-making, and mobilizing progressive ideologies. No process of de-ideologization, however, should be understood as fixed, universal, or prefigured. The form that a specific process assumes is dependent on the context in which it is enacted. Therefore, in what follows, I offer several examples to illustrate some, but certainly not all, of the ways that de-ideologization processes have materialized in different socio-historical contexts.

\section{1 | Re-symbolization}

If dominant ideologies furnish the subjective and the social with meaning (i.e., they symbolize our experience) by eliminating contradiction (Eagleton, 1991; McGowan, 2019), we can understand de-ideologization as an effort to re-symbolize experience so that contradiction is made salient within our interpretative frames. Put differently, when conceived of as a mode of re-symbolization, de-ideologization aims to articulate how politics, subjectivities, collective struggle, and social systems are not at one with themselves. Re-symbolization reminds us that changing the world and the people in it depends not on appreciating external differences (e.g., tolerating the interests of all groups), but acting on internal contradictions (e.g., advancing struggles that are intolerant of capitalist interests that depend on the exploitation of the majority). Psychologists working with activists can undertake re-symbolization in many ways, such as through facilitated group discussions, availing institutional resources, reading groups, reflexive dialogue, or non-linear communicative practices, like artistic production (see Malherbe, 2021). Incorporating contradiction into our collective visions of emancipation (i.e., an intersectional vision of socialism) in these ways can assist us, as political subjects, in guarding against these visions collapsing into abstraction or unreproachable dogma (see Žižek, 1989).

Re-symbolization can assist people to see, with more clarity, where pressure must be applied within a given system (i.e., the gaps in its ideology) so as to reveal how this system fails to attain 
self-identity through its own logic (McGowan, 2019). As such, re-symbolization does not operate without reference to dominant ideology (see Žižek, 2020). On the contrary, people can draw upon the logic and language of dominant ideologies to immanently challenge these ideologies and deconstruct them from within (Laclau, 1996). For instance, because neoliberal capitalist ideology is predicated largely on the value of individual freedom, psychologists can draw on the institutional resources available to them (e.g., venues, communication technology, transportation) to assist political organizers to draw on this same value to justify demands for universal healthcare provision. One's freedom, after all, depends on being healthy enough to exercise this freedom. In so doing, attention is drawn to how the austerity that marks actually existing neoliberalism contradicts neoliberalism's ideological values. When the demand is placed on neoliberal ideology to deliver on its promises of freedom and opportunity, its contradictions are exposed. It is in this respect that re-symbolization can weaken the potency of oppressive ideology.

Psychologists should not conceive of re-symbolization as existing only at the level of political discourse. Wielding de-ideologization for purposes of re-symbolization can also take the form of direct action which exposes the contradictions of dominant ideologies and, in so doing, re-signifies value. Action of this sort exists on individual and collective levels, each of which is connected to the other in particular ways. At the collective level, Marxists might point to the labor strike as the exemplary act for re-symbolizing capitalism's contradictory make-up, but there are plenty of other examples here, including consumer boycotts, withholding reproductive labor, and various other 'anti-value' modes of resistance which challenge how capitalist institutions place greater value on commodities than they do on the lives which (re)produce these commodities (Harvey, 2017). For psychologists, these collective re-symbolizing acts which enunciate and exacerbate capitalism's contradictions serve as important de-ideologizing efforts with which to become involved, either as citizens (e.g., marching, protesting, and striking) or as psychologists (e.g., assisting activists with the psychic toll of political organizing).

Looking to the individual level of the re-symbolizing act, psychologists can work with activists to resist subjective ideological interpellation by refusing capitalism's oppressive subject positions and the expectations attached to these (Althusser, 2014). One need not embody the subjectivity of a socially obedient and exhausted worker, for instance, to be considered a decent or well-adjusted individual. When people are hailed by the subjectivities offered by an emancipatory political project like intersectional socialism, they can begin to re-symbolize their psychic adjustment in terms of contradiction. Anti-capitalist revolt, resistance, and refusal-and the intense affects that these actions give rise to-can, indeed, be re-symbolized as normal reactions to an abnormally exploitative capitalist system. Psychological interventions should allow for contradiction within perceptions of the self so that we may de-ideologize illusions of self-mastery which accompany ideological perceptions of subjectivity (Malherbe, 2021). Psychologists should work with people to refuse capitalism's fictive assertions of subjective wholeness (achieved, for instance, via an adherence to meritocratic ideology), and instead conceptualize subjectivity as always developing with and through the demands of an anti-capitalist politics. Transforming subjectivities in this way can allow for new, emancipatory ways of knowing, which is to say that in re-symbolizing our ontological contradictions, activists are able to co-construct epistemologies that are sensitive to contradiction (McGowan, 2019).

In addition to individual and collective re-symbolizing acts, psychologists can also work with people to enact aesthetic re-symbolization, which is to say, using art as a mode of re-symbolization. Although much art reinscribes dominant ideology and/or aestheticizes radical politics (Malherbe, 2021), truly political art can facilitate ways of seeing that which are not readily symbolized and that lie beyond the grip of capitalism's utilitarian ideology (Eagleton, 1990). The 
so-called 'epic theatre' of the playwright Bertolt Brecht provides us with a useful example here. Brecht's plays draw on what he called the Verfremdungseffekte (or, the alienation effect), whereby that which people typically take for granted - the familiar - is made to seem alien, or strange (Eagleton, 1976). Brecht's plays achieve such alienation in various ways, such as actors stepping out of character or making it clear that they are reciting rehearsed lines; repeated reminders that the audience is watching a play; and/or having the play explained to the audience (Ezcurra, 2012). Inculcating within audiences feelings of alienation in these ways, Brecht argued, has the potential to shock audience members into thinking critically about the contradictions and socio-historical processes which undergird reality. In turn, audiences may act to reconstitute the familiar in more egalitarian ways (Malherbe, 2021). Brecht would also repeatedly rewrite his plays in accordance with audience reactions, thus emphasizing that interpretations of society and subjectivity are not bound to historical inevitability (Ezcurra, 2012). Our perceptions and experiences of reality can always be re-symbolized. Brecht's work is demonstrative of how art can liberate interpretation by moving with and through contradiction, giving to audiences more than what they already have by projecting new possibilities for social relations. As such, audiences of art can be solicited into thinking beyond what is immediately available within dominant perceptions of their present conjuncture (Kornbluh, 2019). Art's re-symbolizing power lies in its ability to viscerally stretch perceptions beyond the ideological constraints of a given society (see Watkins \& Shulman, 2008). In this sense, art can flesh out some of the problematics inherent to contradiction in ways that are more powerful than spoken or written language, which tends to strain under the demands of linearity and coherence. It is because art does not require expertise that it can contribute to less alienating ways of knowing (Eagleton, 1990), with artists understood, in this way, as producers of politicized knowledge (Holert, 2020). Psychologists should be alert to the conscientizing potential here (see Freire, 1972; Montero 1994), whereby interiorizing aesthetic knowledges can lead to the exteriorization of such knowledge, allowing people to move from art to action (Teo, 2018). Psychologists can work with artists and activists to hail both through a single subjectivity that is able to re-symbolize contradictory experience in powerful, psychically appealing ways which encourage action from audiences. Community psychology, in particular, has harnessed the re-symbolizing potential of art in especially productive ways (see Watkins \& Shulman, 2008). Sonn et al. (2015), for instance, demonstrate how young people who took part in a participatory theatre project were able to use their art to re-symbolize and disrupt perceptions of themselves and others, offer to audiences new ways of relating and belonging, and campaign for the resources required to action an antiracist politics.

Liberation psychology's emphasis on reflexivity means that psychologists and the activists with whom they work should include themselves within the scope of re-symbolization (see Malherbe, 2018). Certainly, if activist efforts intend on taking power and remaking society in more equal ways (Kornbluh, 2019; McGowan, 2019), the political or activist self cannot be made sacrosanct, or be understood as a 'beautiful soul' shorn of all contradiction (see Žižek, 1989). Our political horizons collapse into unreason and fail to advance beyond the level of fantasy if the self is positioned as entirely free from that which is being opposed under capitalism (e.g., alienation, internal suffering, greed). Reflexivity demands that psychologists and political activists work together to re-symbolize the contradictions that lie within their subjective embodiments so that these contradictions are not understood as unsurpassable failures of the self, but as points of psychological reflection that inform how they work together to advance the objectives of an intersectional socialism (see Bohrer, 2019). Although the more equal society that one fights for will not resolve the subjective contradictions that mark self-identity, an awareness of and reflexive engagement with these contradictions can inform how people live out their political convictions. 
Psychologists can work with activists to engage critically with-rather than repress-subjective contradiction, including unconscious desires that may contradict one's politics (Malherbe, 2021). A person's individual 'failures', in this respect, can be politically educational. Psychologists and activists can, together, grapple with the tensions inherent to this imperative of 'failing better' within their liberatory strivings and the subjectivities which these strivings produce (see McGowan 2019), all while disidentifying from those ideological fantasies which promise to alleviate subjective contradiction altogether (Bloom, 2013; Malherbe, 2021).

\section{2 | Solidarity-making}

Solidarity denotes 'a relation forged through political struggle which seeks to challenge forms of oppression' (Featherstone, 2012, p. 5). To ensure that such struggle is not co-opted, it is crucial that solidarity is always led from below, and forged through connections that are made in the context of political struggle, rather than through the dispassionate mechanisms belonging to the elite (see Featherstone, 2012). By recognizing oppression and exploitation, solidarity urges those who receive benefits from oppressive systemic arrangements (benefits which rarely translate into psychological wellbeing, Watkins \& Shulman, 2008) to act against these material interests (Wright, 2019). Solidarity, therefore, demands that people reject the ways by which certain subjectivities are rewarded and enjoyed under a capitalist system based on exploitation (Malherbe, 2021).

The solidaritous relation rests on an ideological premise that rejects capitalism's competitive individualism by demonstrating how individual freedoms are, in fact, tied to the progress of the collective, no matter how disparate the struggles of these individuals may seem (see Harvey, 2017; Therborn, 1980). Even when 'my struggle' appears to be disconnected from that which is 'yours', the solidarity relation looks to realize how all struggles can operate together within capitalism's broader matrix of oppression. We saw this in 1973 when, after Pinochet's military coup in Chile, Scottish factory workers refused to service Chilian jet fighter planes that had landed in Glasgow, almost grounding the dictator's airforce altogether (Gilbey, 2018). In a more recent example, Palestinian activists who, upon learning that the teargas which police were firing at antiracist protesters in Ferguson, Missouri, was the same kind that had been fired at them by the Israeli military, began Tweeting advice to those in Ferguson on how to effectively deal with being teargassed (e.g. washing one's eyes out with milk, rather than water) (Davis, 2016). In forging the solidarity relation, we recognize that under capitalism, the existence of each contradiction is dependent on and constituted through other contradictions, which renders anti-capitalist resistance a holistic project (Žižek, 2020). Any appeal to labor struggles, for example, must also appeal to antiracist and feminist struggles if, indeed, capitalism's exploitative totality is to be meaningfully challenged.

For psychologists working with social movements, it is crucial to keep in mind that solidarity-building not only holds socially transformative potential but also changes the subjects who work towards this transformation. For instance, David Featherstone (2012) recounts that in the interwar period, anticolonial political activists - such as Chris Braithwaite-played a central role in challenging the imperial visions of solidarity that were being pursued by powerful maritime labor unions in the United Kingdom. As a result of the activism of Braithwaite and his comrades, many white union members joined in the effort to decolonize labor movements, challenging their racial biases in the process. As such, the solidarity relation produced different ways of knowing and being with others. De-ideologizing solidarity-making demands that psychologists 
work with activists to centralize, rather than obfuscate, contradiction. In this, the psychologist strives to build solidarities with people by refusing mainstream psychology's ideological hermeneutics and prescriptions, such as attempts to hail subjects through free-market ideologies (e.g., the customer, the client, or the service-provider). Further, psychologists must reject moralistic conceptions of solidarity which rely on notions of pure subjectivity that posit the virtuous self, the righteous ingroup, or the unreproachable Other. When solidarity is grounded in such moralistic notions of subjectivity, we risk organizing around a false sense of coherence that obfuscates unequal relations of power within social movements (see Žižek, 2020). Solidarity-building requires that people work towards instating a transformative process wherein political identifications are continually renegotiated and challenged in accordance with an emancipatory politics, such as intersectional socialism.

So far, then, we can understand solidarity-building as endeavoring to create new ways of relating to and being in the world (Featherstone, 2012), with the terms of solidarity, and our subject positions within this, struggled over in relation to a broader socialist project that challenges unequal and intersecting relations of power. This is not to say that our vision of intersectional socialism will be contradiction-free, but rather that engaging with the contradictory antagonisms of this project is a potentially generative, conscientizing, and democratic enterprise, whereas engaging the contradictions of subjectivity is an inherently individualising affair that is typically geared towards realizing fantasies of subjective coherence. One might, therefore, understand solidarity as limited when it is based on subjective similarity instead of a commitment to a common, but always negotiated, political vision of socialist emancipation. In this sense, and contra to much mainstream psychology, solidarity-building seeks to engage 'universalism' as an always-developing process that is created and articulated in different ways within the context of political struggle (see Laclau, 1996). For example, when psychologists working in contexts of anti-capitalist struggle attempt to build the solidarity relation with other psychologists by sharing effective mental health practices, they should not seek to impose their particular as a kind of psychological universal. Rather, they should look to identify connections between different contextually-situated psychological knowledges (akin to how protesters in Palestine shared their experiential knowledge of struggle with activists in the United States, see Davis, 2016).

The subject enters into solidarity through, and is remade by, its commitment to a particular politics of liberation, and psychologists are able to work with collectives to negotiate and articulate this complex political relation. Yet, seeking to make solidarity and subjectivity through politics, rather than constructing politics and solidarity through false conceptions of a stable subjectivity, is not to discount the importance of identity-based movements. Historically, female-led trade unions, for instance, have been crucial to addressing patriarchal currents that run through so many labor unions (Featherstone, 2012). Nonetheless, such identity-based movements remain committed to a set of anti-capitalist political objectives (which are struggled over in the very act of forging of solidarities) that speak to and hail subjectivities in particular ways (e.g., a socialist feminism that speaks to issues of equality among women and gender non-conforming people). Conscientizing people towards broad political goals, and building solidarity through these goals, is an endeavour that is psychological inasmuch as it is political. Addressing unequal relations of power within movements, speaking to issues of democracy within leadership, accommodating differing political tactics, and implementing inclusive activist strategies all entail much psychic tension. Psychologists can assist activists to articulate these tensions for one another within a process of 'loving critique' that engages difference and contradiction, in an open manner, not for purposes of retribution, but to embolden one's commitment to intersectional socialism through an understanding of experiences that may not be one's own (Bohrer, 2019). As such, solidarity 
is facilitated via the development of an emotional knowledge which recognizes that although people suffer differently under capitalism - and that these differences must be attended to in organizing spaces (e.g., through democratic decision-making)—comrades can address a common suffering, together, by building an intersectional socialism (see Malherbe, 2021)

\section{3 | Mobilizing progressive ideologies}

Far from spontaneous or inevitable (see Ratner, 2019b), collective resistance demands intense organizational efforts of which progressive ideological mobilization is key. I take progressive ideological mobilization to mean the construction of new and counter-hegemonic ideologies that resist dominant modes of ideological interpellation (Therborn, 1980), and that aim to hail political subjects in ways that reject capitalist consumerist logic (Esposito \& Perez, 2014). In other words, progressive ideologies seek to make appealing — and thus also sustainable —an anti-capitalist politics that is sensitive to the racialized and gendered components of capitalism. It is a decolonizing, feminist socialism that takes seriously issues of ecology, mental health, disability, and freedom. As such, because political projects like neoliberal feminism, white laborism, and Black capitalism adhere to the oppressive logic of capitalism in one way or another, they are-crudely put-not enough, and thus cannot be considered progressive ideologies. Mobilizing progressive ideologies is, in short, an attempt to organize perceptions along a hermeneutic that aligns with an intersectional and a collective opposition to capital (see Bohrer, 2019). In these ways, progressive ideologies define the human via a consciousness of belonging to an ethico-political community (Balibar, 1995).

Although de-ideologization appears antithetical to the task of progressive ideological mobilization, the two are-perhaps paradoxically_related to one another in particular ways. Certainly, ideological mobilization rests on the kind of ideological critique inherent to de-ideologization. The picture of emancipation developed by a socialist feminist ideology, for instance, is reacting to patriarchal capitalist ideology. De-ideologization's emphasis on retrieving people's experiences in ways that reject dominant ideological frameworks allows people to mobilize around repressed or forgotten histories that can give rise to new ideological frameworks and which are able to transform their subjectivities (see Malherbe, 2020). These new, counter-hegemonic ideologies will-like dominant ideologies-be marked by contradiction, however their purpose will not be exploitative. To the contrary, such counter-hegemonic ideologies can assist activists to organize through ideological frames that make intersectional socialism commonsensical and appealing (see Eagleton, 1991; Wright, 2019).

Drawing upon de-ideologizing tactics to advance progressive ideological mobilizations allows people to enunciate a progressive politics, and thus also political relations, through a militant vitality that rejects capitalist interpellation (see Laclau, 1996). For instance, C. L. R. James (2001) recounts that during the Haitian Revolution, insurrectionary slaves took the notions of 'liberty' and 'equality', as they were developed in the French Revolution, and dislodged them from their Eurocentric moorings to advance new, decolonizing subjectivities (see also Featherstone, 2012). Similarly, ideological mobilization can untether the notion of diversity from neoliberal hermeneutics (i.e., leadership structures that reflect a multitude of capitalist subjectivities), and instead reconfigure diversity so that it denotes a radical inclusion within emancipatory political movements (see Harvey, 2017). In resisting and remaking capitalist semiotics in these ways (see Ratner, 2019b), people can begin to not only think and act outside of elite ideological interests, but construct new, emancipatory ideological frames around which to organize their political activity. 
What, then, is the role of psychology in mobilizing progressive ideologies, if indeed psychology is to have any role at all? As some have insisted (e.g., Parker, 2007), psychology's institutional embeddedness might prevent it from ever being successfully reoriented along progressive ideological lines. However, I wish to argue that the point is not to change psychology. Rather, psychologists should try to use their psychological training for politically progressive purposes; to use psychology progressively. This might entail assisting activists with the trauma, psychic stress, and failures that accompany a commitment to an anti-capitalist politics, or it could involve psychologists facilitating spaces wherein activists can address and reformulate politically regressive contradictions within their movements (i.e., strengthening the intersectional elements of a socialist politics, or bolstering the socialist commitments of intersectional activism).

To mobilize progressive ideologies is to construct different ideological fantasies of wholeness which emphasize intersectional solidarity and mutualism (see Glynos, 2001). Ideological mobilization is, in this very specific sense, able to offer activists a sense of coherence around which to establish a political agenda that speaks to crises, identifies enemies, as well as transforms and mobilizes subjectivities, all while indicating what is possible and how these possibilities can be achieved (Therborn, 1980). Accordingly, psychological work should emphasize that although these new fantasies will not resolve the problems of subjective contradiction, they can allow for intersubjective connections that are based on the anti-capitalist values which sustain people's commitment to socialist struggle (see Bloom, 2013; Featherstone, 2012). As Anna Kornbluh (2019, p. 164) writes, 'There are worlds beyond capitalism, worlds of other desires, other drives, other antagonisms. They are not more satisfying, but they are more just', which is to say that deliverance from all subjective contradiction and psychic anguish need not be the goal of social activism. Rather, the point is to construct a fairer world that does not structurally reward greed and competitive individualism. The material and political alternatives that activists seek to build should thus be assessed by and held accountable to the ideological values of these worlds that lie beyond capitalism (Wright, 2019).

\section{6 | CONCLUSION}

Within the liberation psychology paradigm, de-ideologization denotes a process of reconstructing consciousness so as to produce an understanding of the world outside of elite ideological hermeneutics (Montero, 2007). In this article, I have drawn on Marxist and psychoanalytic theory to examine the role that contradiction and ideology play within de-ideologization efforts. I do so by considering three de-ideologizing processes: re-symbolization, solidarity-making, and mobilizing progressive ideologies. Work of this kind is, by its very nature, challenging. Nonetheless, I have attempted to argue that contradiction can offer a useful, yet almost entirely overlooked, concept around which to organize de-ideologization processes from within the liberation psychology paradigm.

In exploring processes of re-symbolization, solidarity-making and mobilizing progressive ideologies, I do not claim to have provided any kind of exhaustive list of de-ideologizing strategies and tactics. Rather, it is my wish that fleshing out de-ideologization in these very particular ways will encourage others to build upon, critique, and engage further with de-ideologization and contradiction, and to consider what these concepts could mean for the practice of a psychology of liberation. Where my focus in this article falls on contexts of collective political resistance, others may wish to explore how de-ideologization can inform institutionalized or legislative modes of resistance, as well as resistance as it exists in people's everyday lives. It may also be pertinent for 
psychologists to explore the pedagogical or clinical implications of de-ideologization, and the role that contradiction plays in these areas. It is, however, crucial that psychologists continually work to de-center psychology within de-ideologization processes, lest they capitulate to individualization or mainstream psychology's muted-and thus all the most insidious-ideological allegiances to neoliberal capitalism. To de-ideologize is to be led by grassroots struggles, be they oriented towards direct action, embedded within institutions, or enacted in people's quotidian lives. The forms which de-ideologization processes assume are, in other words, always determined by struggle, and never by the limited ideological horizons of possibility which have been made available by mainstream psychology's disciplinary dictums.

\section{ACKNOWLEDGEMENTS}

Conversations with Professors Shahnaaz Suffla and Mohamed Seedat supported me in conceptualising this article. The author received no funding.

\section{CONFLICT OF INTEREST}

The author has no conflict of interest to declare at this time.

\section{DATA AVAILABILITY STATEMENT}

Data sharing is not applicable to this article as no new data were created or analysed in this study.

\section{ORCID}

\section{Nick Malherbe (D) https://orcid.org/0000-0002-4968-4058}

\section{REFERENCES}

Althusser, L. (2014). On the reproduction of capitalism: Ideology and ideological state apparatuses. Verso.

Augoustinos, M. (1999). Ideology, false consciousness and psychology. Theory \& Psychology, 9(3), 295-312.

Balibar, E. (1995). The philosophy of Marx. Verso.

Billig, M. (1991). Ideology and opinions: Studies in rhetorical psychology. Sage.

Bloom, P. (2013). Fight for your alienation: The fantasy of employability and the ironic struggle for self-exploitation. Ephemera: Theory \& Politics in Organizations, 13(4), 785-807.

Bohrer, A. (2019). Marxism and intersectionality: Race, gender, class and sexuality under contemporary capitalism. Columbia University Press.

Burton, M., \& Kagan, C. (2005). Liberation social psychology: Learning from Latin America. Journal of Community \& Applied Social Psychology, 15(1), 63-78.

Danziger, K. (1990). Constructing the subject: Historical origins of psychological research. Cambridge University Press.

Davis, A. Y. (2016). Freedom is a constant struggle: Ferguson, Palestine, and the foundations of a movement. Haymarket Books.

Dobles, I. (1999). Marxism, ideology and psychology. Theory \& Psychology, 9(3), 407-410.

Eagleton, T. (1976). Marxism and literary criticism. Methuen \& Co.

Eagleton, T. (1990). The ideology of the aesthetic. Basil Blackwell.

Eagleton, T. (1991). Ideology: An introduction. Verso.

Esposito, L., \& Perez, F. M. (2014). Neoliberalism and the commodification of mental health. Humanity \& Society, 38(4), 414-442.

Ezcurra, M. P. (2012). On "shock": The artistic imagination of Benjamin and Brecht. Contemporary Aesthetics, $10(4)$.

Featherstone, D. (2012). Solidarity: Hidden histories and geographies of internationalism. Zed Books.

Foster, D., Haupt, P., \& de Beer, M. (2005). The theatre of violence: Narratives of protagonists in the South African conflict. HSRC Press. 
Freire, P. (1972). Pedagogy of the oppressed. Herder and Herder.

Galtung, J. (1990). Cultural violence. Journal of Peace Research, 27(3), 291-305.

Gilbey, R. (2018). On yer way, Pinochet! The factory workers who fought fascism from Glasgow. The Guardian. https://www.theguardian.com/film/2018/nov/01/on-your-way-pinochet-factory-workers-fought-fascismfrom-glasgow-chile-coup-nae-pasaran

Glynos, J. (2001). The grip of ideology: A Lacanian approach to the theory of ideology. Journal of Political Ideologies, 6(2), 191-214.

González Rey, F. (2016). Paths, development and discontinuity of some critical approaches to psychology in Latin America: What happened in that history? Annual Review of Critical Psychology, 10, 642-662.

Hall, S. (1987). Gramsci and us. Marxism Today, 16-21.

Harvey, D. (2017). Marx, capital, and the madness of economic reason. Oxford University Press.

Holert, T. (2020). Knowledge beside itself: Contemporary art's epistemic politics. Sternberg Press.

Holland, D. (2017). The nature of the political reconsidered. Journal for the Theory of Social Behaviour, 47(1), 32-57.

James, C. L. R. (2001). The black Jacobins: Toussaint L'ouverture and the San Domingo revolution. Penguin Books.

Kornbluh, A. (2019). The order of forms: Realism, formalism, and social space. The University of Chicago Press.

Laclau, E. (1996). Emancipation(s). Verso.

Malherbe, N. (2018). Expanding conceptions of liberation: Holding Marxisms with liberation psychology. Theory \& Psychology, 28(3), 340-357.

Malherbe, N. (2020). Articulating liberation psychologies of culture. Journal of Theoretical and Philosophical Psychology, 40(4), 203-218.

Malherbe, N. (2021). A psychopolitical interpretation of de-alienation: Marxism, psychoanalysis, and liberation psychology. Psychoanalysis, Culture \& Society, 26(3), 263-283.

Martín-Baró, I. (1994). Writings for a liberation psychology. Harvard University Press.

Marx, K., \& Engels, F. (1972). The German ideology. International Publishers.

McGowan, T. (2019). Emancipation after Hegel: Achieving a contradictory revolution. Columbia University Press.

Montero, M. (1994). Consciousness raising, conversion, and de-ideologization in community psychosocial work. Journal of Community Psychology, 22(1), 3-11.

Montero, M. (1997). Political psychology: A critical perspective. In D. Fox \& I. Prilleltensky (Eds.), Critical psychology: An introduction (pp. 233-244). Sage.

Montero, M. (2007). The political psychology of liberation: From politics to ethics and back. Political Psychology, 28(5), 517-533.

Parker, I. (2007). Revolution in psychology: Alienation to emancipation. Pluto Press.

Ratner, C. (2019a). Psychology's contribution to socio-cultural, political, and individual emancipation. Springer.

Ratner, C. (2019b). Neoliberal psychology. Springer.

Roberts, R. (2015). Psychology and capitalism: The manipulation of mind. Zero Books.

Sonn, C. C., Quayle, A. F., Belanji, B., \& Baker, A. M. (2015). Responding to racialization through arts practice: The case of participatory theater. Journal of Community Psychology, 43(2), 244-259.

Teo, T. (2018). Outline of theoretical psychology: Critical investigations. Palgrave Macmillan.

Teo, T., \& Afşin, B. (2020). The impossible conditions of the possibility of an alter-global psychology. In L. Sundararajan, K.-K. Hwang, \& K.-H. Yeh (Eds.), Global psychology from indigenous perspectives (pp. 159-174). Palgrave Macmillan.

Therborn, G. (1980). The ideology of power and the power of ideology. Verso.

Tissaw, M. A., \& Osbeck, L. M. (2007). On critical engagement with the mainstream: Introduction. Theory \& Psychology, 17(2), 155-168.

Watkins, M., \& Shulman, H. (2008). Toward psychologies of liberation. Palgrave Macmillan.

Wright, E. O. (2019). How to be an anticapitalist in the 21st century. Verso.

Žižek, S. (1989). The sublime object of ideology. Verso.

Žižek, S. (2014). Trouble in paradise: From the end of history to the end of capitalism. Allen Lane.

Žižek, S. (2020). A left that dares to speak its name: 34 untimely interventions. Polity. 
How to cite this article: Malherbe, N. (2021). De-ideologization, liberation psychology, and the place of contradiction. Journal for the Theory of Social Behaviour, 1-17. https:// doi.org/10.1111/jtsb.12322 